\title{
Die Moderne Benadering tot Infeksiesiektes
}

\author{
O.W. Prozesky, M.B.Ch.B., M.D. (Pret.). \\ Direkteur, Nasionale Instituut vir Virologie en Professor in Virologie, Universiteit van Pretoria.
}

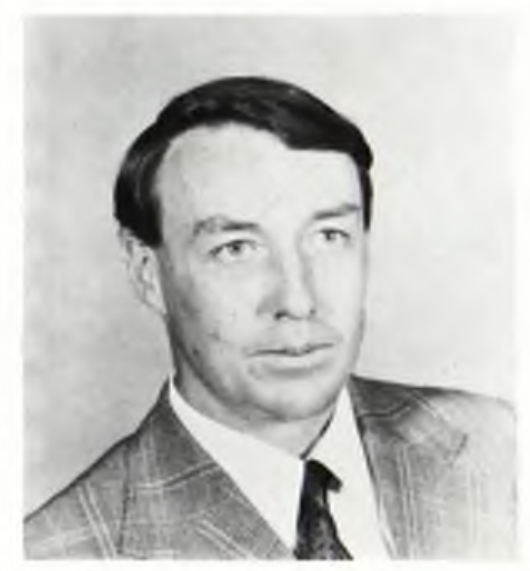

\section{SUMMARY}

The combat against infectious diseases stands at the moment on the threshold of ; et another revolution, similar to the previous one which was brought about by antibiotic therapy. This new revolution is not attributed to a remedy or group of new remedies but rather to a new conviction, a realisation, that prevention is immeasurably better than treatment, and that community health, in the broadest sense, is immeasurably more effective than the single-patient approach of the past.

$\mathbf{I}$

NFEKSIESIEKTES was tot onlangs toe naas oorlog, aardbewings en hongersnood, beskou as natuurrampe wat uit hulle aard maar altyd moes voorkom. In die hedendaagse Geneeskunde het die belang van infeksiesiektes baie verminder en is dit tot ' $n$ groot mate verdring deur ander gesondheidsprobleme. Dit is alleen nou en dan, wanneer ' $n$ bevolking getref word deur 'n katastrofiese epidemie, dat ons plotseling op 'n onaangename wyse herinner word daaraan dat ons ou tradisionele vyande, die patogene mikro-organismes, nog altyd hulle virulensie behou het en nog 'n ernstige bedreiging kan wees.

Die toenemende bevolkingsgetalle en die daarmee gepaardgaande bevolkingsdigtheid, asook die toenemende bewegings van mense op die lokale sowel as internasionale vlak deur middel van die moderne vervoerwese, konfronteer ons egter met die probleem dat infeksiesiektes nou vinniger en beter kan versprei en dat internasionale grense makliker oorskry word as voorheen. Daarenteen het die doeltreffendheid van geneeskundige voorkomingsmaatreëls en opsporingsmetodes van gevalle sowel as die gebruik van rekenaarmetodes vir statistiese epidemiologie, ons in " $n$ beter posisie geplaas om epidemiese siektes te kan beheer en te kan voorkom. Die belangrikste enkele faktor met die grootste invloed is egter ongetwyfeld die vervaardiging van doeltreffende en veilige entstowwe deur moderne tegnologie. 'n Totale nuwe benadering is nie net nou nodig nie maar word deur hierdie faktore op ons afgedwing. Die harde ekonomiese werklikhede van die geweldige direkte en indirekte koste wat deur infeksiesiektes veroorsaak word, het ook deurgedring tot die finansiers van geneeskundige dienste en die term koste-tot-voordeel-verhouding van maatreëls om siektes te bekamp, word algemeen gebruik en gehoor. Tereg het die moderne bestuurswese ook die veld van infeksiesiektes betree tot groot voordeel van almal. 


\section{DIE UITWISSING VAN INFEKSIESIEKTES}

'n Unieke gebeurtenis het plaasgevind in Oktober 1977 toe die laaste geval van pokke in die wêreld opgespoor is in Merka Town. Somalië ${ }^{1}$. Die pasiënt wat herstel het en nou gesond is, besef gladnie waarom sy 'n belangrike historiese figuur geword het nie. Sy is die simbool van "n stryd so oud soos die mensdom tussen die Variolavirus en die mens. Die stryd om die pokvirus uit te wis, is tot die verwondering van selfs diegene wat die nouste daarby betrokke was, uiteindelik gewonne en ons moet nou alleen nog die virus wat in enkele laboratoria bewaar word, behoorlik inperk. Tensy hulle ontsnap kan die siekte nooit weer voorkom nie.

Die betekenis van hierdie gebeurtenis mag vir die oningeligte waarskynlik nie so belangrik lyk nie, maar na nadenke en ondersoek, kan 'n mens nie anders as om oorstelp te staan voor die betekenis en omvang van die gebeurtenis nie. Dit is die eerste keer in die geskiedenis dat die mens deur doelbewuste optrede "n infeksiesiekte nie net beperk of beheer nie. maar totaal kon uitwis. Die belang hiervan is die volgende:

1. Verpligte inenting teen pokke wat nog altyd "n prosedure was wat ' $n$ betekenisvolle aantal persone gevaarlike en permanent skadelike komplikasies laat opdoen het, kan nou wêreldwyd gestaak word. Die besparing aan gerief, koste, mannekrag en tyd (dink net aan oponthoud by internasionale lughawens) wat dit teweeg sal bring. is byna onberekenbaar groot.

2. Die geld en fasiliteite wat so beskikbaar gestel word deur dit nie meer vir die beheer van pokke te spandeer nie. kan nou gebruik word om ander siektes te bekamp.

3. Ons het die insig. ervaring en tegnieke ontwikkel om ander siektes op soortgelyke wyse uit te roei.

4. Die publiek sal waarskynlik 'n versterkte geloof ontwikkel in entstowwe en die geneeskunde en daardeur beter saamwerk in die bekamping van ander siektes deur entstowwe. Dieselfde geld hopelik vir geneeskundige personeel!

Die ooglopende vraag is natuurlik: Waarom kon juis pokke uitgeroei word en aan watter vereistes moet voldoen word om dit te vermag? Tydens die operasie om die siekte uit te roei, is gevind dat die volgende vereistes geld:

1. Die siekte moet net in mense voorkom sodat daar nie nog 'n alternatiewe bron van die siekte kan bestaan soos " $n$ diersoort waaroor beheer moeilik of gladnie uitgeoefen kan word nie.

2. Vir opsporing van alle gevalle moet 'n duidelik klinies waarneembare siektetoestand bestaan. Daar moet nie 'n toestand van latente siekte wees nie, met ander woorde. gesonde draers wat die siekte ongesiens versprei nie.

3. Daar moet 'n doeltreffende entstof beskikbaar wees om die siekte mee te voorkom. Die entstof moet oor die volgende eienskappe beskik: (a) Een dosis moet langdurige of verkieslik permanente immuniteit veroorsaak

(b) Toediening moet maklik wees, sodat groot spanne van selfs ongeskoolde werkers dit kan hanteer.

(c) Die entstof moet 'n goeie houbaarheid hê. sodat dit oor lang afstande vervoer kan word en selfs onder swak bergingstoestande nie bederf nie. Gevriesdroogde entstowwe het hierdie eienskappe alreeds tot 'n groot mate.

4. Internasionale optrede moet moontlik wees en genoeg geld moet beskikbaar wees vir volgehoue en onafgebroke optrede. Periodieke optrede is nutteloos vir die doel van siekteuitwissing.

Wanneer voldoen word aan hierdie vereistes, is dit tans moontlik om 'n infeksiesiekte uit te roei. Siektes wat as die volgende teikens beskou word, is masels en poliomiëlitis. Masels is nog altyd die algemeen ernstigste infeksiesiekte wat mense opdoen en dit voldoen wel aan die vereistes, met die uitsondering dat daar moontlik "n latente vorm van die siekte bestaan (subakute skleroserende pan-enkefalitis). Laasgenoemde is egter baie skaars en het nog nooit masels veroorsaak nie. Die ander probleem wat masels betref, is dat die entstof wat tans beskikbaar is, ' $n$ beperkte houbaarheid het, maar nuwe stabiliserende stowwe vir byvoeging by die entstof is ontwerp en word tans getoets. Die probleem met poliomiëlitis is dat die oorgrote meerderheid infeksies wel subklinies is en dat gevalle baie moeilik opgespoor kan word. Dit is dus waarskynlik dat die volgende siekte op die lys vir uitwissing, masels is. Masels veroorsaak tans "n geweldige las van dood en siekte wat veral rus op die ontwikkelende lande $^{2}$ en dit sou vir die wêreld as geheel geweldig baie beteken indien dit uitgeroei sou kon word. Geboortebeperking sal natuurlik die plek van afsterwe deur masels moet neem wat bevolkingstoename betref om nie die probleem van oorbevolking in die ontwikkelende lande te vererger nie.

\section{HOSPITALISASIE VAN PASIËNTE MET INFEK- SIESIEKTES}

Elke geval van "n infeksiesiekte wat in "n hospitaal opgeneem word. moet beskou word as 'n mislukking van die gesondheidsdienste wat die siekte moes voorkom het. Voorkoming van 'n geval kos ten minste een duisendmaal minder as hospitaalbehandeling van 'n pasiënt, sonder dat die indirekte koste in ag geneem word soos die koste van die aansteeklikheid wat nou weer verdere gevalle tot gevolg het. Sommige onkoste word eers jare later veroorsaak, soos wanneer ' $\mathrm{n}$ kind wat masels gehad het, as gevolg daarvan tuberkulose opdoen. of besmet raak met antibiotika-bestande bakterieë wat dan weer ander probleme skep ${ }^{4}$.

Vroeër, toe hospitaalbehandeling meestal bestaan het uit verpleging-en-met-rus-laat en intensiewe sorg en aggressiewe optrede teen siektes meestal baie moeilik of onmoontlik was, is die gevaar wat ' $\mathrm{n}$ besmetlike pasiënt inhou vir die bevolking emstiger geag as die standaard van hospitaalbehandeling wat hy sou geniet. Daar was ook voor die koms van goeie entstowwe. noodwendig baie meer gevalle wat hospitalisasie nodig gehad het as tans. Die Afsonderingshospitaal of die sogenaamde Koorshospitaal het in die verlede aan die vereistes voldoen. Dit was op sy ergste "n hospitaaltjie. swak voorsien en half vergete, êrens in die 
buitewyke. Sommige was niks meer as outydse "peshuise" nie en die enigste fasiliteite wat hulle werklik gebied het, was die vermoë om die pasiënt af te sonder van ander mense.

Die beeld het nou totaal verander. Die aantal werklike gevalle en dus die aantal pasiënte wat moes opgeneem word, het verminder en die belangstelling van geneeshere in die veld het gekwyn. Dit het tot verdere onbruik, verwaarlosing en personeeltekorte in hierdie soort hospitale gelei. Intussen het die behandelingsmoontlikhede vir pasiënte in ander inrigtings fantasties verbeter en het die standaard van die sorg vir pasiënte wat ernstig siek is, skerp gestyg. Afsondering van die pasiënt is nou dikwels van baie minder belang as die standaard van die sorg wat hy benodig, aangesien die breë bevolking in elke geval meestal deur entstof beskerm is teen die siekte. Die beste behandeling met al die fasiliteite van intensiewe sorg en laboratoriumondersteuning kan nie meer gebied word in die afsonderingshospitaal nie.

Die volgende faktor, wat die benadering tot selfs die mees gedugte epidemiese aansteeklike siektes totaal verander het, is die tegnologie wat ontwikkel is vir afsondering van die pasiënt self in ' $\mathrm{n}$ gewone hospitaalomgewing. Eers is beter oorjasse, skoene, maskers, brille, ontsmetmiddels en lugreëlingstelsels gebruik om 'n veiliger metodiek te verseker. Die volgende groot stap het gevolg toe wegdoenbare spuite en ander tipes instrumente beskikbaar gestel was. Met 'n goeie outoklaaf en verbrander kan enige hospitaal nou besmette materiaal vinnig en doeltreffend hanteer en ontsmet sonder enige gevaar vir die personeel en die omgewing. Die lugdigte plastieksakkie en ander houers het in hierdie verband geweldig baie beteken vir veilige vervoer en uiteindelike dekontaminasie van besmette materiaal, monsters en so meer.

Intussen is daar in die afgelope dekade ook groot vooruitgang gemaak met die tegnieke en apparate om kiemvrye diere mee te versorg. Hierdie diere was en is tans nog nie alleen van onskatbare waarde vir navorsing en insig in die probleme van infeksiesiektes en immunologie nie, maar het ook, as belangrike neweproduk, aan ons die apparate en tegnieke gebied om pasiënte veilig en gerieflik te kan afsonder in gewone hospitale.

Die kern van hierdie stelsels is die pasiënte-isolator ${ }^{3}$, 'n plastiese lugdigte tent met baie doeltreffende lugversorging en filtrasie van lug om alle mikro-organismes daaruit te verwyder. Daar is twee basiese soorte van isolator, naamlik die positiewe-druk isolator vir die pasiënt wat teen organismes van ander mense in sy omgewing beskerm moet word en die negatiewe-druk isolator vir die pasiënte wat aan gevaarlike infeksiesiektes ly en waarteen die personeel en die omgewing beskerm moet word. Eersgenoemde word byvoorbeeld gebruik vir pasiënte wat aan uitgebreide brandwonde ly of aan leukemie, terwyl laasgenoemde gebruik word in die geval van siektes te wyte aan klas 4 patogene, die gevaarlikste klas infektiewe organismes ${ }^{5}$. Hierdie siektes bied spesiale probleme wat later bespreek sal word.

Daar is tans geen redes waarom pasiënte met infeksiesiektes nie in die gewone goedtoegeruste hospitaal versorg kan word nie en die Gesondheidswet van 1977 maak voorsiening dat hulle die verantwoordelikheid van die Provinsiale owerhede sal word. Geen nuwe afsonderingshospitale word beplan as aparte entiteite nie hoewel die groter Provinsiale hospitale toegerus is met afdelings vir infeksiesiektes. 'n Eenvoudige algemene reël is dat die pasiënt daar geplaas word waar hy die beste behandeling kan geniet wat sy toestand vereis en dat die probleem van sy besmetlikheid of afsondering aldaar plaaslik opgelos moet word deur gebruik van die moderne tegnieke wat daarvoor beskikbaar is. Die dae toe hy verban is na ' $n$ afsonderingshospitaal, waar fasiliteite noodwendig soms nie heeltemal voldoen het aan sy vereistes nie, is verby.

\section{KLAS 4 INFEKSIESIEKTES}

Patogene organismes word in 4 klasse verdeel volgens die bedreiging wat hulle vir die mens inhou ${ }^{5}$, met klas 1 as die minder gevaarlike einde van die skaal en klas 4 as die uiters gevaarlike groep. Laasgenoemde sluit in siektes soos Marburgkoors, Lassakoors, Ebolakoors en Kongokoors. Hierdie siektes is meestal dodelik, daar is geen entstof beskikbaar nie en behandeling is dikwels onsuksesvol. Die enigste wapens wat teen klas 4 organismes tot ons beskikking is, is afsonderingsmaatreëls om die siekte te beperk, passiewe immuniteit in die vorm van bloedkomponente wat verkry is van enkele pasiënte wat wel die siekte oorleef het en 'n aantal middels wat nog as eksperimenteel beskou word, soos interferon.

Vir hierdie soort pasiënte is spesiale maatreëls nodig. Drie soorte pasiënte-isolators is beskikbaar. Die grootste is 'n hospitaalmodel wat die pasiënt vir ongeveer 3 weke kan huisves en wat selfs beperkte wandelinge toelaat sonder dat die afsondering enigsins verbreek word. Die pasiënt word gedurig deur die handskoene hanteer en intensiewe sorg en selfs beperkte chirurgie is moontlik. Die middeslag isolator is 'n lugvervoerisolator wat met batterye voorsien is en wat die pasiënt vir 48 uur kan huisves tydens vervoer na die hospitaalmodel. Die kleinste is "n draagbaar wat met droë selle werk en waarin die pasiënt oor kort afstande vervoer kan word. Al drie hierdie isolatortipes sluit met lugdigte aansluitpoorte aan by mekaar vir gevaarlose oordrag van 'n pasiënt van een na die ander. Suid-Afrika het 'n stelsel van lugvervoer- en hospitaalisolators ingestel om pasiënte met hierdie siektes in die toekoms te vervoer en te versorg. Spesiale veiligheidslaboratoriumgeriewe vir die diagnose en bewaking van die pasiënte se toestand is ook beskikbaar6.

\section{DIE IDENTIFIKASIE VAN NUWE PATOGENE}

In die afgelope 5 jaar is verbaisende vooruitgang gemaak in die navorsing om die oorsaaklike organismes van verskeie infeksiesiektes te identifiseer. Waar die oorsaak van hepatitis tot onlangs nog as 'n byna onoplosbare probleem beskou is, is daar nou meteens 3 virusse bekend, elk met sy eie epidemiologie, wat die siekte veroorsaak ${ }^{7}$. Ook in die geval van aansteeklike buikloop by babas, een van die grootste gesondheidsprobleme van die ontwikkelende lande, is groot vooruitgang gemaak toe die rolle van die rotavirus ${ }^{8}, \mathrm{Cam}$ pylobacter fetus ${ }^{9}$ en die dermpatogene vorms van $E s$ cherichia coli ${ }^{10}$ duidelik geword het. So ook is 'n geheimsinnige ernstige longontsteking gevind om tewyte te wees aan 'n klein bakterie, die sogenaamde legioensiektebakterie. 
Al hierdie nuwe kennis is onmiddellik beshikbaar vir die bekamping en voorkoming van die toestande. Hierdie nuwe inligting stel epidemioloë onmiddellik instaat om te verstaan hoe die siektes oorgedra en versprei word, en kan die mikrobioloë nou aktief entstowwe of behandelingsmetodes ontwerp om hulle teë te werk. Waar ons 'n tyd gelede nog gedink het dat verskeie siekte-oorsake te moeilik is om op te spoor, het nuwe laboratoriumtegnicke die deure telkens weer vir ons oopgesluit om nuwe aspekte te herken en te bestudeer. Een van die belangrikste vereistes om 'n siekte te kan beheer. is kennis in verband met die oorsaaklike organisme en daarom is nuwe vooruitgang nou moontlik.

\section{INFEKSIE MET BESTANDE BAKTERIEË}

Bestandheid teen antibakteriële middels is 'n kommerwekkende verskynsel wat toenemend by in groot aantal bakterieë voorkom. Suid-Afrika is een van die lande in die wêreld wat die ergste te kampe het met die probleem. Dit is duidelik volgens syfers van antibiotikaverbruik, dat ons geneeshere geweldige hoeveelhede en 'n groot verskeidenheid antibiotika voorskryf, dikwels sonder inagneming van die moontlike gevare van hulle optrede. Weens die hoë insidensie van infeksiesiektes soos masels, wat dan dikwels gevolg word deur longontsteking in ons swart- en kleurlingbevolkings, word die kinders wat in die swakste lewensonstandighede grootword, al vroeg intensief blootgestel aan 'n verskeidenheid kragtige breëspektrum-antibiotika. Die grootste probleem in hierdie verband is gestel in Durban en Johannesburg en hierdie twee stede het verlede jaar die twyfelagtige eer gehad om die eerste in die wêreld te wees waarin in variant van Streprococcus pheumoniae geselekteer is wat bestand is teen konvensionele antibiotik $a^{4}$. Hierdie probleem word wêreldwyd in so "n ernstige lig beskou. dat daar internasionale optrede is om die organismes op te spoor en uit te roei.

Die grondoorsaak van die probleem van antibiotikamisbruik mag wees dat siektevoorkoming in plek van behandeling nie genoeg aandag kry nie. Dit is tot 'n mate tewyte aan die passiwiteit van die ouers en die bevolking sowel as aan 'n gebrek aan insig by 'n deel van ons geneeskundige personeel. wat hulle nog altyd meer toespits op die terapie van enkele pasiënte as op siektevoorkoming in die bevolking as geheel.

Alle hospitale behoort 'n streng antibiotika-beleid neer te lê en te volg. Die geneeskundige beroep was nog altyd tereg baie streng met sy reëls oor die standaard van kwalifikasie, kennis en ondervinding van die geneesheer veral wanneer hy of sy sekere operasies uitvoer. Baie van ons geneeshere het egter al gepraktiseer toe antibiotika ontdek is en alleen die minderheid hou hulle op hoogte van sake in hierdie belangrike en vinnig veranderende veld. Die korrekte gebruik van antibiotika is deesdae net so gebiedend noodsaaklik as die korrekte gebruik van verdowingsmiddels. Wat sal dit ons baat as ons duur en fantastiese middels onbruikbaar op die rak bly terwyl ons pasiënte weer moet sterf aan bakteriële siektes soos in die vorige eeu?

Die bestandheid van bakterieë teen antibiotika, ontsmetmiddels en bestraling word dikwels beheer de ur infeksie van die bakterieë met oordraagbare genetiese elemente, of plasmiede. Etlike virulensiefaktore wat organismes patogeen mak, word ook deur sulke plasmiede bepaal. Die gevaarlik- ste patogene bakterieë is die klas wat kombinasies besit van plasmiede, bestandheidsoordragsfaktore genoem. en virulensieplasmiede. 'n Groot aantal spesies bakterië kan hierdie plasmiede vrylik uitruil en oordra. sodat dit deesdae soms net so belangrik is om te weet met watter plasmied ons te kampe het as met watter bakterie die pasiënt besmet is. Die moderne bakterioloog moel die bakteriële infeksie deesdae ook leer benader vanaf die oogpunt van die bakteriële genetikus. Dit is ook vir hom nodig om die organismes in sy omgewing en die hospitale daarin te leer ken en dop te hou en nie net meer soos in die verlede net op die identifikasie van die organisme wat 'n spesificke probleem in 'n spesifieke pasiënt veroorsaak, te konsentreer nie. Verder moet hy die plig op hom neem om persoonlik betrokke te raak by die higiëne en die antibiotika-gebruik in sy omgewing, om te sorg dat daar korrek en voorkomend opgetree word waar moontlik en dat wanneer daar tot behandeling oorgegaan word, dit doelgerig en sekuur geskied.

Ten laaste net "n opmerking oor die standaarde van water, voedsel en melk. Daar is ongelukkig nog 'n houding by sommige geneeskundiges dat " $n$ intraveneuse inspuiting in hoogsopgeleide geneesheer benodig terwyl die suiwering van "n groot stad se water en rioolafvloei vir miljoene mense maar aan in minimaal gekwalifiseerde tegnikus oorgelaat kan word sonder dat ons daarin hoef belang te stel.

Die modeme benadering vereis dat ons nie net die siek pasiënt as " $\mathrm{n}$ geheel moet beskou nie, maar ook die bevolking en sy lewenswyse en gewoontes. "Vyf ster behandeling" in "vyf ster hospitale" kan nooit slaag as die algemene gesondheidsstandaarde maar net "een ster" is nie!

\section{DIE BELANG VAN EPIDEMIOLOGIE}

Suid-Afrika het agter geraak in die veld van infeksiesiektes wat die uiters belangrike aspekte betref van die opleiding van epidemioloë en die daarstelling van 'n behoorlike epidemiologiese diens. Die moderne epidemiologie is al vir ongeveer " $n$ dekade "n selfstandige wetenskap in sy eie reg. maar ons vind dat dit hier by ons net "n minder belangrike aspek van algemene geneeskunde vorm. Ons pluk gedurig wrange vrugte as gevolg daarvan en sal nog vir etlike jare so moet aangaan want ons agterstand is groot. Dic opsporing, aanmelding en daaropvolgende optrede teen infeksies kan nie meer op 'n passiewe wyse alleen verrig word en maar oorgelaat word aan die distriksgeneesheer wat nie waarlik tyd daarvoor het nic en ook nie behoorlik daarvoor opgelei is nie.

'n Epidemiologiese span wat. sodra infeksies aangemeld word, vinnig ter plaatse ondersoek kan instel, vakkundige besluite kan neem en dadelik ter plaatse stappe kan doen om die bedreiging onmiddellik die hoof te bied, is nou 'n vereiste. Tans word dit op 'n ad hoc-basis gedoen, maar dit het ook baie nadele. Ons kan nie meer verwag dat die aanmeldingsvorm wat na in paar maande eers dic regte persoon bereik, voldoende moet wees nie. Ons moet oorgaan tot aktiewe opsporing en bewaking om die infeksiesiektes vroeg, voor die probleem hand uitgeruk het, op te spoor en in die kiem te smoor. Epidemiologie is nic net die hou van statistieke en die teken van grafieke nie! Dit is inteendeel 'n uiters aktiewe en hoogs interessante en belangrike werk. waarvan alleen 'n klein onderafdeling die insameling en 
verwerking van statistieke is. Die gesondheidsdienste van Rusland en Amerika beskik oor die beste ontwikkelde epidemiologiese dienste en dit is waarskynlik nie toeval nie dat, hoewel hulle baie groot lande is met baie groot bevolkings, hulle per kapita syfers vir infeksiesiektes baie laag is.

\section{DIE GEBRUIK EN EFFEKTIWITEIT VAN ENT- STOWWE}

Die mees effektiewe, veiligste en goedkoopste maatreël wat teen enige infeksiesiekte getref word, is die doelgerigte en algemene toediening van 'n entstof. Die lid van die gesondheidspan wat nie aktief meehelp in hierdie verband nie, tree onverantwoordelik op. Ons vind tot ons verbasing nog geneeshere. verpleegsters en ouers wat bewerings soos "ek glo nie daaraan nie" of ".n mens moet natuurlike weerstand opbou" aanbied met of geen logiese argumente om hierdie standpunte te ondersteun nie, of argumente wat gebaseer is op feite wat al dekades gelede verkeerd bewys is. Die probleem is egter dat sulke persone nie besef watter $\mathrm{k}$ waad hulle doen nie. Die kind wat nie sy entstof ontvang nie en dus vatbaar is vir siekte en dood is ongelukkig die kleinste deel van die probleem wat nou ontstaan. Wanneer egter besef word dat wanneer hy die siekte opdoen hy daardeur. 'n honderd of meer ander kinders in die buurt in gevaar stel en weer optree as 'n nuwe verspreidingspunt en oorlewingsmoontlikheid wat die organisme teen uitwissing beskerm, lyk die saak veel ernstiger. Ons tree nog veels te goedmoedig op teen hierdie vorm van ondergrawing wat aan niks anders as blote onkunde tewyte is nie. Die moderne entstowwe is uiters veilig en doeltreffend onder alle omstandighede waarin hulle behoorlik gebruik word. Voordat sulke stowwe gebruik mag word. word hulle aan geweldige streng toetse onder alle omstandighede onderwerp en sou nie toegelaat gewees het as daar enige twyfel bestaan het oor hulle doeltreffendheid of veiligheid nie.

Een aspek wat egter nou meer aandag geniet, is die verskillende vereistes waaraan entstofprogramme in verskillende dele van die wêreld moet voldoen. Dit is byvoorbeeld nutteloos om in ons Suid-Afrikaanse swart- of kleurlingbevolkings, masels-entstof eers op 15 maande ouderdom toe te dien, of polio-entstof aan skoolgaande kinders, soos in die ontwikkelde lande. Die siektes wat ons probeer voorkom, het op daardie leeftyd alreeds lankal voorgekom en daarom moet die entstowwe op 6 maande ouderdom of selfs vroeër toegedien word. Dit bring egter weer mee dat moederlike immuniteit die entstof se werksaamheid onderdruk en dat skraagdosisse later, op ongeveer I jaar tot 18 maande ouderdom. nou nodig is. Die blanke bevolking weer benodig entstof op dieselfde tyd as in die ontwikkelde lande. Hierdie belangrike besef is "n direkte produk van " $n$ behoorlike epidemiologiese diens en beklemtoon weereens die belang van so "n diens vir die bestryding van infeksiesiektes.

'n Laaste probleem is dié van die gebruik van entstowwe by kinders wat aan een of ander ligte ongesteldheid ly. "n Goeie algemene reël om te onthou, is dat, as die kind te siek is om die entstof wat so veilig is, goed te verdra. is hy definitief veels te siek om die siekte self op te doen!

Die bekamping van infeksiesiektes staan op die oomblik op die drumpel van nog "n omwenteling soos die vorige een wat teweeggebring is deur antibiotiese terapie. Hierdie nuwe omwenteling is nie tewyte aan "n middel of groep nuwe middels nie. maar eerder aan "n nuwe gesindheid, "n besef. dat voorkoming oneindig beter is as behandeling. en dat volksgesondhe id in die breë, oneindig meer effektief is as die enkel-pasiënt-benadering van die verlede.

\section{VERWYSINGS}

WHOWeekly Epidem. Rec. 18. 125 (1978)

KIPPS. A. \& KASCHULA. R.O.C. Virus pneumonia following measles. $S A$ Med. I 50.1083

3. CLAUSEN. L... et al. (1978). Isolation and handling of patients with dangerous infectious disease. S.A. Med. J. 53,238

APPELBAUM. P.C. el al. (1977). Sireprococcus pneumoniae resistant to penicilAPPELBAUM. P. C el al. (1977). Sireprococt
lin and chloramphenical. Lances (ii) 995.

5. CLASSIFICATION OF ETIOLOGICAL AGENTS ON THE BASIS OF HAZARD (1974) th Ed DHEW Publication No. (CDC) 75-8118. US Govem ment Printing Office. Washington. DC

6. GOMPERTS. E.D. et al. (1978). Handling of highly infectious material in Clinical Pathology laboratory and in a viral diagnostic unit. S.A. Med. J. 5.3 .243 7. PROZESKY. O.W. (1978). Editorial: Viral hepatitis - some recent developmenis. S.A. J. Hosp. Med. \$, 129.

8. SCHOUB B D. R OOSTHUIZEN G MCGILLIVRAY AND PROZESKY O.W (1978). Prevalence of antibodies to a Rotavirus in Black and White Populations in South Africa. S. A. Med. J.53, 159.

9. DE MOL. P \& BOSMANS E. (1978). Campylobacter enteritis in central Africa Lancer (i). 604

10. FREIMAN. 1.. el al. (1977). A microbiological study of gastro-enteritis in blach infants. S.A. Med. J. 52.261. 